\title{
The botanical macroremains from the prehistoric settlement Kalnik- Igrišče (NW Croatia) in the context of current knowledge about cultivation and plant consumption in Croatia and neighboring countries during the Bronze Age
}

\author{
Sara Mareković1* ${ }^{*}$, Snježana Karavanić2 ${ }^{\text {, Andreja Kudelić2 }}$, Renata Šoštarić \\ 'Division of Botany, Department of Biology, Faculty of Science, University of Zagreb, Marulicev trg 20/ll, 10000 Zagreb, Croatia \\ ${ }_{2}^{2}$ Institute of Archaeology, Louis Gaja 32, 10000 Zagreb, Croatia
}

\begin{abstract}
This paper presents the results of the first extensive archaeobotanical research into a Bronze Age site in Croatia. The aim of the study was to reveal what plants were consumed (grown) at Kalnik-Igrišče (NW Croatia) in the Bronze Age and to realize if the plant diet of the local population differed from that of the inhabitants in neighboring countries.

The results show that all plant macrofossils found at Kalnik-Igrišče can be classified into one of four functional groups: cereals, cultivated legumes, useful trees and weeds. As much as $98 \%$ of the findings are of cereals and legumes. The most abundant species found are Panicum miliaceum (millet), Hordeum vulgare (barley), Vicia faba (faba bean), Triticum aestivum ssp. aestivum (bread wheat), Triticum turgidum ssp. dicoccon (emmer wheat) and Lens culinaris (lentils). The findings from Kalnik-Igrišče do not differ from the findings of neighboring countries, indicating that there were similar diets and agricultural/plant-collecting activities throughout the whole of the studied area (Bosnia and Herzegovina, Slovenia, Serbia, Italy, Austria and Hungary).
\end{abstract}

Keywords: Kalnik-Igrišče; NW Croatia; Bronze Age; carbonized plant macrofossils; human nutrition

\section{Introduction}

Investigations into human nutrition in the Bronze Age in Croatia are very rare; the only data related to it are from Nova Bukovica [1] and Monkodonja near Rovinj [2]. Nova Bukovica-Sjenjak is a site located in the Croatian inland and only two kinds of botanical macrofossils have been recorded; seeds of the faba bean (Vicia faba) and fragments of the acorn (Quercus sp.) [1]. The Monkodonja site is a historical village, surrounded by strong dry stone walls, situated five kilometers from Rovinj [3]. At Monkodonja, archaeologists recorded four plant species: the grapevine (Vitis vinfera), oat (Avena sp.), faba bean (Vicia faba) and grass pea (Lathyrus sativus) [2].

On the other hand, studies of Bronze Age sites in the surrounding countries are more numerous: Bosnia and Herzegovina (2 sites), Serbia (3), Slovenia (5), Austria (11) and Italy (28). Insight into Late Bronze Age plant remains from Hungary was acquired from Gyulai [4], in which the author summed up all archaeobotanical researches in that

\footnotetext{
* Corresponding author. Email: sara.marekovic@biol.pmf.hr
} Handling Editor: Łukasz Łuczaj area to date. In order to provide easier access to all the data, a comparison of the findings from neighboring countries with the results from Kalnik-Igrišče is presented in tabular form in Appendix S1.

\section{The context of the findings (Kalnik-Igrišče site)}

Samples analyzed in the study come from the site KalnikIgrišče, located on the southern slopes of Mount Kalnik (north Croatia; Fig. 1), at about $500 \mathrm{~m}$ a.s.l. Archaeological research into the multilayer site Kalnik-Igrišče began in the year of 2006 and was completed in 2012. The archaeological excavation covered in total an area of 60 square meters located on a terrace.

Under layers with the traces of habitation from the Middle Ages, Roman period and the Late Iron Age we discovered well preserved remains of a Bronze Age house. This was a layer (SU 14) of a burned house with large quantity of charcoal, carbonized cereals and broken pottery. Several layers under layer 14 were formed as a result of the collapse of the house and erosion. The research included the western and northern edges of the structure. Construction elements of the house have been preserved in the form of postholes and a partially preserved stone structure, along the western edge of the house. 


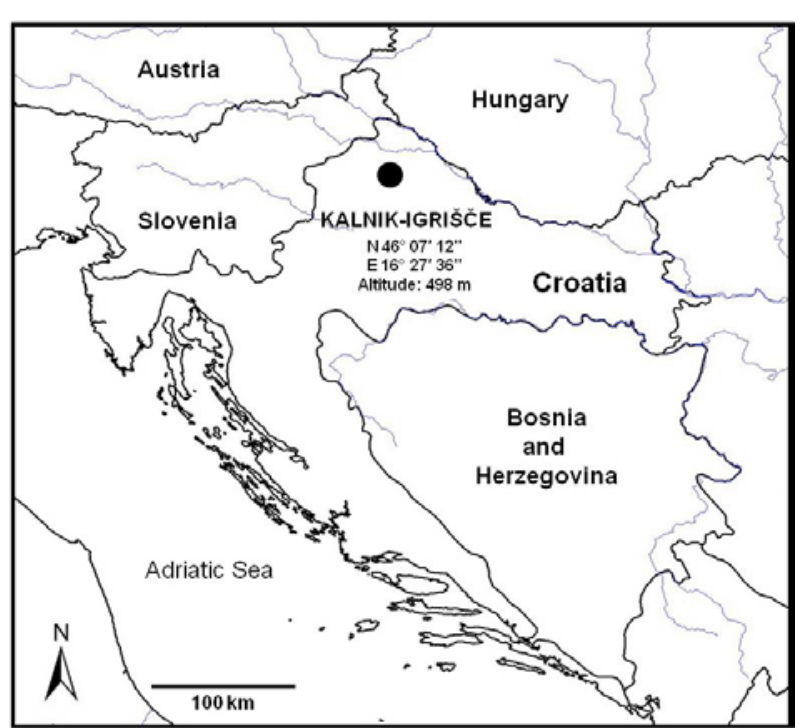

Fig. 1 The location of Kalnik-Igrišče site.

The house was destroyed in a fire, which was evident from the findings of carbonized grains and pottery fragments damaged by high temperatures. Although the dwelling is not yet completely explored, it is assumed that this part of the house was used for food storage. The evidence for this is the large number of vessels for storage and preparation of food as well as items of plant food that have been found [5,6].

Radiocarbon analysis (conducted in the Beta Analytic Radiocarbon Dating Laboratory) of the wheat grains found at Kalnik-Igrišče with $95 \%$ confidence placed the sample in the period between 840 and $790 \mathrm{BC}$ (Late Bronze Age), which is also confirmed by the analysis of pottery found on the site. The pottery belongs to the Ha B phase of the late Urnfield culture. Based on their stylistic traits, the potsherds fit best in the assemblage of the Ruše cultural group in Slovenia. In the Late Bronze Age a mostly unique culture was present on the wide region of Danube, the southeastern Alps and the northern edge of the Balkans. At that time a unique archaeological culture, manifested primarily in the burial of cremated decedents in large flat urn fields, was created. Bronze metallurgy reached its highest achievements in prehistoric Europe, while trading and cultural connections were established with distant areas [6].

The aim of our research was to investigate what plants were consumed (grown) at Kalnik-Igrišče (NW Croatia) in the Bronze Age and to see if the plant diet of the local population was similar to that of the inhabitants in neighboring countries.

\section{Material and methods}

During an archaeological excavation campaign in 2008, 55 samples were collected and without flotation put in plastic bags and delivered to the Faculty of Science, Department of Biology (Botany) in Zagreb for archaeobotanical analysis. First, the volume of each sample was measured and then all the plant remains were isolated from the soil. The soil from our samples was loose enough to be dry sieved, so we did not use water recovery techniques. For dry sieving we used sieves with mesh diameters of 2.51 and $0.315 \mathrm{~mm}$ and obtained three fractions. The fraction with the smallest particles had no botanical remains in the first 15 randomly picked samples, so no more checking was done of this fraction. Some samples rich with macrofossils (Tab. 1) were reduced by grid-method $[7,8]$ to one third of their overall volume in order to save research time and energy.

After isolation, determination of plant macrofossils was done. For determination of plant species (genus/families) we used seed atlases [9-11], textbooks [12,13] and some scientific and qualification papers with useful illustrations and explanations [14-18]. For the taxa determination the carpological collection (under establishment) of the Botany Division was found very helpful. The nomenclature of plant species was done according to Cappers and Neef [19]. All the determined macrofossils and their frequencies are listed in Tab. 1.

With the help of the computer program Motic Images Plus 2.0 and the camera placed on the microscope, the average dimensions (height, length and width or radius) were measured for cereals and cultivated legume species (with more than 5 findings), which were found at both Kalnik-Igrišče and the comparison site Stillfried an der March [20]. For comparison site was chosen Stillfried an der March, because from that site we had data on dimensions of carbonized remains, of the same plant species like the ones from Kalnik-Igrišče.

All the plant species found were classified into one of four categories (cereals, cultivated legumes, useful trees and weeds) and their occurrence and abundance were analyzed.

After review of the scientific archaeobotanical literature about the Bronze Age sites from Croatia and neighboring countries (Slovenia, Hungary, Austria, Italy, Bosnia and Herzegovina, and Serbia), comparison was made between the literature and the Kalnik-Igrišče site, and conclusions were drawn about the plant diet of the Bronze Age human population living in the area.

\section{Results}

A total of 55 samples were subjected to archaeobotanical research. The volume of the investigated samples was 136.5 l. We isolated and identified 69116 plant remains, of which only $13(0.02 \%)$ were not carbonized (Viburnum lantana); however, they represent contamination from the present time. When we calculated (for the samples in which only $1 / 3$ of the sample was analyzed) the assumed total amount of plant remains, we got a total number of 139581 macrofossils present at the site (Tab. 1). Tab. 1 shows that in the analysis of 69116 macrofossils, we identified 18 species (67 146 remains), 5 genera (597 remains), 2 families (34 remains) and 14 (246 remains) insecurely determined species or genera (so called "cf." taxa). Three seeds remained undetermined. The number of macrofossils undetermined was small because poorly preserved or morphologically atypical remains were assigned to broad categories such as 
Tab. 1 The list of all taxa found at the late Bronze Age site Kalnik-Igrišče, with accompanying data about type of a macrofossil, category of taxa, number of isolated and assumed number of macrofossil on the site.

\begin{tabular}{|c|c|c|c|}
\hline Taxa & Type of macrofossils & Number of isolated macrofossils & Assumed number of macrofossils \\
\hline \multicolumn{4}{|l|}{ Cereals } \\
\hline Avena sp. & grain & 68 & 248 \\
\hline cf. Avena sp. & grain & 5 & 13 \\
\hline Cerealia & grain & 279 & 407 \\
\hline Hordeum vulgare $\mathrm{L}$. & grain & 12735 & 27283 \\
\hline cf. Hordeum vulgare $\mathrm{L}$. & grain & 61 & 61 \\
\hline Panicum miliaceum L. & grain & 22570 & 45452 \\
\hline Secale cereale $\mathrm{L}$. & grain & 5 & 15 \\
\hline cf. Secale cereale L. & grain & 2 & 2 \\
\hline Setaria italica (L.) P. Beauv. & grain & 433 & 833 \\
\hline cf. Setaria italica L. & grain & 29 & 57 \\
\hline Triticum aestivum ssp. aestivum $\mathrm{L}$. & grain & 6230 & 12338 \\
\hline Triticum cf. aestivum ssp. aestivum L. & rachis fragment & 1 & 3 \\
\hline Triticum aestivum ssp. spelta (L.) Thell. & grain & 3900 & 8412 \\
\hline Triticum aestivum ssp. spelta (L.) Thell. & glume base & 31 & 75 \\
\hline Triticum cf. aestivum ssp. spelta (L.) Thell. & glume base & 39 & 115 \\
\hline Triticum monococcum ssp. monococcum $\mathrm{L}$. & grain & 399 & 787 \\
\hline Triticum monococcum ssp. monococcum $\mathrm{L}$. & glume base & 38 & 106 \\
\hline Triticum turgidum ssp. dicoccon (Schrank) Thell. & grain & 5735 & 11383 \\
\hline Triticum turgidum ssp. dicoccon (Schrank) Thell. & glume base & 66 & 166 \\
\hline $\begin{array}{l}\text { Triticum cf. turgidum ssp. dicoccon (Schrank) } \\
\text { Thell. }\end{array}$ & glume base & 24 & 62 \\
\hline Triticum sp. & grain & 462 & 1066 \\
\hline $\begin{array}{l}\text { Triticum turgidum ssp. dicoccon (Schrank) Thell./ } \\
\text { Triticum aestivum ssp. spelta (L.) Thell. }\end{array}$ & grain & 811 & 1293 \\
\hline \multicolumn{4}{|l|}{ Cultivated legumes } \\
\hline Lens culinaris Medik. & seed & 4918 & 11056 \\
\hline cf. Pisum sativum L. & grain & 11 & 25 \\
\hline Vicia faba L. & seed & 9053 & 16489 \\
\hline \multicolumn{4}{|l|}{ Useful trees } \\
\hline Cornus mas $\mathrm{L}$. & stone & 1 & 3 \\
\hline Malus sylvestris Mill. & fruit fragment & 31 & 31 \\
\hline Malus sylvestris Mill. & fruit & 207 & 215 \\
\hline Malus sylvestris Mill. & seed & 4 & 9 \\
\hline Quercus sp. & cotyledon (half) & 31 & 61 \\
\hline Quercus sp. & cotyledon fragment & 15 & 19 \\
\hline \multicolumn{4}{|l|}{ Weeds } \\
\hline Bromus arvensis $\mathrm{L}$. & grain & 2 & 2 \\
\hline Bromus secalinus $\mathrm{L}$. & grain & 17 & 37 \\
\hline Bromus cf. secalinus $\mathrm{L}$. & grain & 4 & 10 \\
\hline Echinochloa crus-galli (L.) P. Beauv. & grain & 728 & 1102 \\
\hline cf. Echinochloa crus-galli (L.) P. Beauv. & grain & 64 & 124 \\
\hline Galium aparine $\mathrm{L}$. & seed & 19 & 45 \\
\hline Galium cf. aparine L. & seed & 4 & 12 \\
\hline Galium spurium L. & seed & 10 & 26 \\
\hline Galium cf. spurium $\mathrm{L}$. & seed & 2 & 6 \\
\hline \multicolumn{4}{|l|}{ Unknown } \\
\hline Bromus sp. & grain & 14 & 38 \\
\hline cf. Bromus sp. & grain & 1 & 1 \\
\hline Chenopodiaceae & seed & 1 & 3 \\
\hline Galium sp. & seed & 7 & 21 \\
\hline Poaceae & grain & 33 & 51 \\
\hline Viburnum lantana $\mathrm{L}$. & seed & 13 & 13 \\
\hline Indet. & seed & 3 & 5 \\
\hline$\Sigma$ & & 69116 & 139581 \\
\hline
\end{tabular}


Cerealia (cereals). The Cerealia group consists of cultivated large-grained cereals (Triticum/Hordeum/Secale/Avena), which could not be determined to the genus or (sub)species level, because they were in a poor state of preservation. Tab. 1 also includes the category Triticum turgidum ssp. dicoccon (syn. Triticum dicoccum, emmer wheat) / Triticum aestivum ssp. spelta (syn. Triticum spelta, spelt), to which we allocated wheat grains that have morphological features of both taxa, but do not completely match any of them. The identification of Triticum subspecies was not always easy, because there were many grains without completely clear morphological characteristics of any subspecies. But with the help of literature and the comparative carpological collection, we managed to sort most grains into one of the four subspecies, whose characteristic representatives we show in Fig. 2.

The most frequently found species (>3900 remains) were Panicum miliaceum (millet), Hordeum vulgare (barley), Vicia faba (faba bean), Triticum aestivum ssp. aestivum (syn. Triticum aestivum, bread wheat), T. turgidum ssp. dicoccon (syn.
Triticum dicoccum, emmer wheat), Lens culinaris (lentils) and Triticum aestivum ssp. spelta (spelt; Fig. 3, Tab. 1).

Based on the literature data on the use of certain plant species and customs related to them in the past and the present, we have divided macrofossils found into four categories (cereals, cultivated legumes, useful trees and weeds) which helped us to draw conclusions about the dietary and agricultural habits of the local human population. The numbers of species in each category and the total number of found macrofossils for each category is shown in the graphs (Fig. 4, Fig. 5).

The list of species identified clearly shows that most remains found at this site were intentionally brought to the house for the purpose of being consumed. The number of macrofossils that were accidentally collected together with cultivated plants or otherwise entered the house (for example brought in by the wind, after the house was demolished and became more open to external accidental contamination), is much smaller.
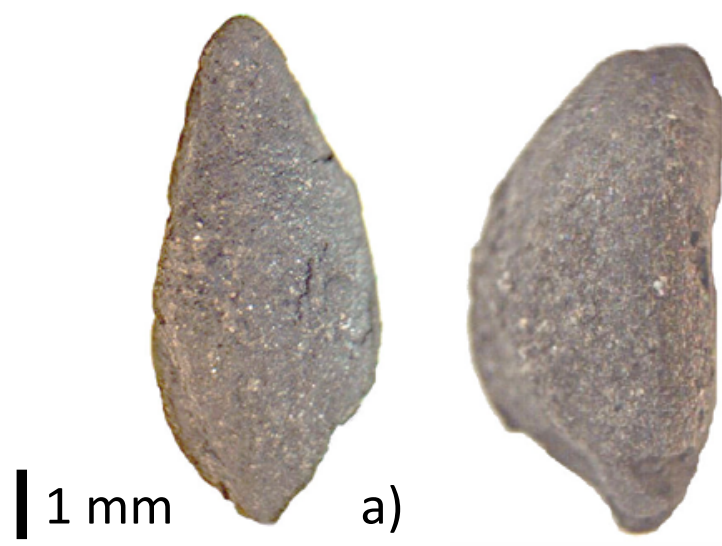

b)

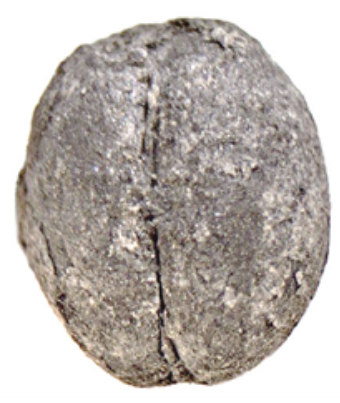

c)

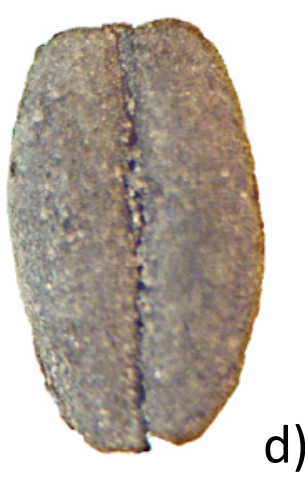

Fig. 2 The morphological differences between Triticum subspecies: T. monococcum ssp. monococcum (a; lateral view), T. turgidum ssp. dicoccon (b; lateral view), T. aestivum ssp. aestivum (c; ventral view) and T. aestivum ssp. spelta (d; ventral view).

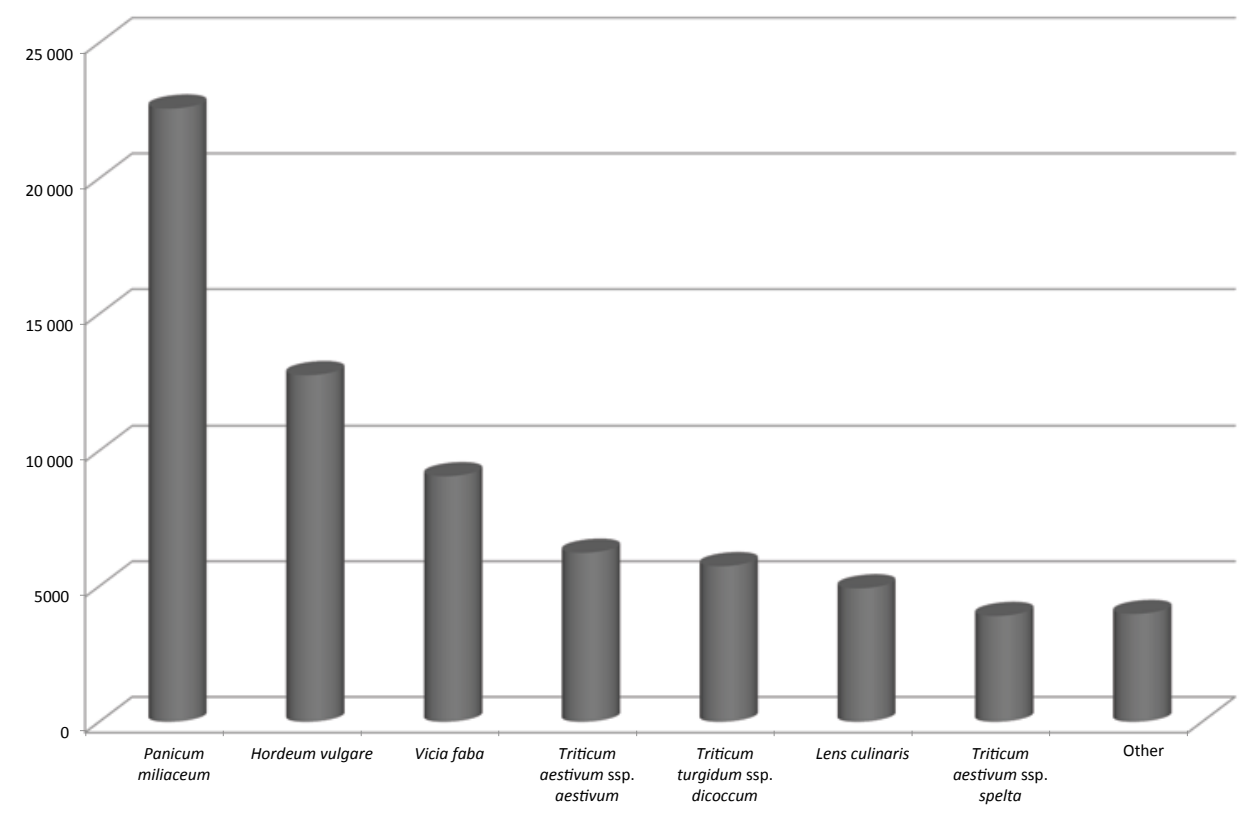

Fig. 3 The amount of the most numerous plant taxa macrofossils found on the Kalnik-Igrišče site. 


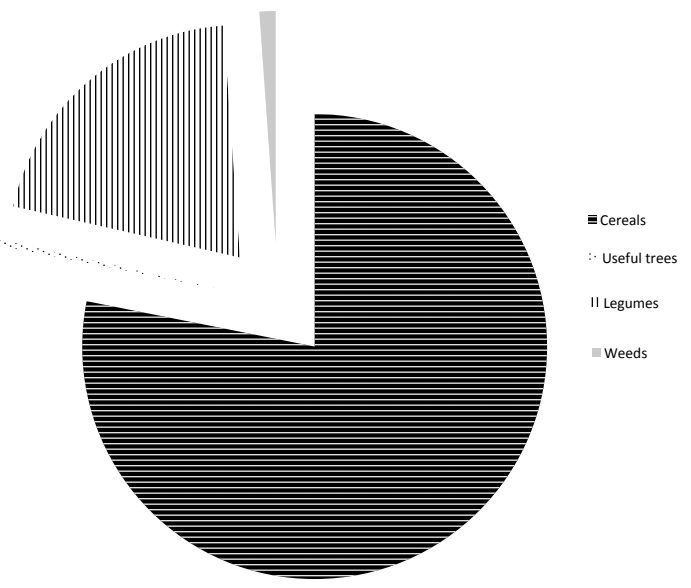

Fig. 4 The percentage of each category, according to the total number of macrofossils from category.

\section{Discussion}

\section{Plant macrofossils from the Kalnik-Igrišče site}

Since all the plant macrofossils were collected from the house floor, the result was expected: that $98 \%$ of the findings were of cereals and legumes. The rest of findings (2\%) consisted of useful tree species, growing in the nearby woods, and weeds, growing as crop admixture.

Legumes are less frequent than cereals, but that does not necessarily mean they had less importance for the human population. Legumes and cereals have always been grown together and were both used in the diet. Legumes were an important source of protein, and cereals are primarily a rich source of carbohydrates. We noticed that at Kalnik-Igrišće there are fewer legumes than cereals, for which there can be many reasons. One of them could be the difference in food preparation; the legumes were most probably soaked before cooking and the cereals roasted, which could make cereals harder and more resistant to disintegration. The remains of lentils are in comparison to cereal remains very fragile [21], so it is possible that a large part of the lentil remains was destroyed before the archaeobotanical investigation(s). It is also possible that at the moment when the house in KalnikIgrišče was burnt, there happened to be more cereals in it, because the legumes were already consumed or maybe even generally less frequently used as food.

It is interesting to note that no oil plants remain (e.g., flax, gold of pleasure, common poppy, etc.) were found on the Kalnik-Igrišče site. Otherwise these are the species that regularly occur in Europe in the (late) Bronze Age [22].

Weed species are represented by a small number of species and in small amounts. Barnyard grass (Echinochloa crus-galli) forms the main part of these findings. This plant is still cultivated in Asia, so it is possible that it may even have been cultivated at Kalnik-Igrišče (or tolerated as crop admixture). Plants of this whole group most likely grew as weeds among cultivated plants and were accidentally brought to the house together with cereals.

The remains of apples (Malus sylvestris), cornelian cherries (Cornus mas) fruit and acorns of oak (Quercus sp.) indicate the fruit collecting activity of the human population.

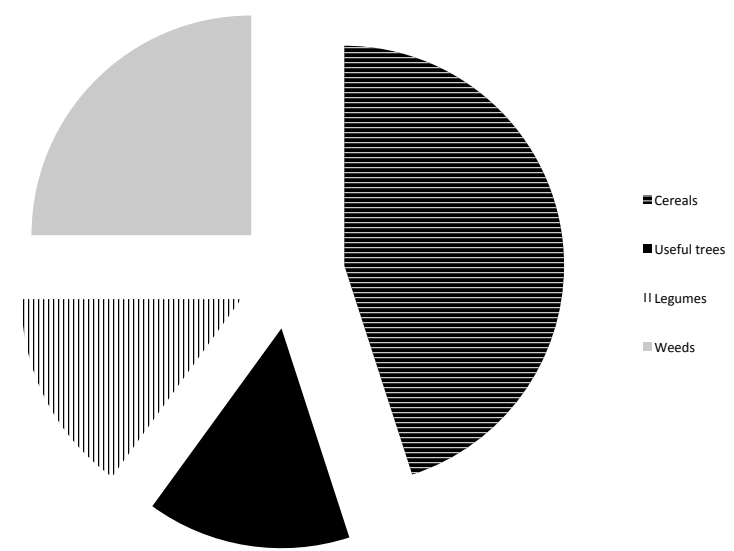

Fig. 5 The percentage of each category, according to the total number of found (sub)species/genera from category.

It is assumed that those remains originate from the vicinity of the site, where they grew as native species. As well as for human nutrition, the species listed could also have been used as a supplement food for animals.

Unfortunately, this research cannot confirm that the local population grew the found plant taxa, because the collected remains from the settlement can primarily prove that the inhabitants consumed and owned that food. For a reliable reconstruction of the paleoenvironment it would be advisable to do pollen analysis (or at least wood charcoal analysis). The pollen analysis could show the human impact on the area around the site. Any cereal pollen found would indicate that the cereals were not only consumed, but also cultivated in the area. Pollen analysis could also show if the woods were replaced with grasslands, which could indicate possible livestock farming. However, close to the village Kalnik-Igrišče there are no appropriate places for collecting pollen samples (fens, lake mud, etc.).

\section{A comparison of findings from the Kalnik-Igrišče site with}

\section{findings from other sites in Croatia and neighboring countries}

Appendix S1 shows the data on the relative representation of the species found at Kalnik-Igrišče and at other Bronze Age sites in Croatia and neighboring countries (Slovenia, Bosnia and Herzegovina, Austria, Hungary, Italy and Serbia).

Until this research, only two Bronze Age sites (Monkodonja and Nova Bukovica) were archaeobotanicaly investigated in Croatia, therefore it was not a surprise that all the species from Kalnik-Igrišče, except Avena sp., Quercus sp. and Vicia faba, were recorded for the first time in Croatia in the Bronze Age.

The comparison of findings from Kalnik-Igrišče with findings from neighboring countries indicates that in continental Croatia plant species used for food (and probably also cultivated there) were also present in the neighboring countries. From the Tab. 1 is evident that millet and barley, the most numerous cereals from the studied site, were also recorded in most of the sites compared and in large quantities in Serbia, Italy, Austria and Hungary. The mentioned cereals can primarily be used for making porridge and/or bread. 
Regarding wheat, the situation in Kalnik-Igrišče is similar to that found in surrounding countries. The species that appear are the same, but the abundance and distribution vary from country to country and from locality to locality. It is interesting to note that in Austria Triticum aestivum ssp. spelta and T. aestivum ssp. aestivum were never recorded with a higher relative quantity than "a lot of" ("xx"), while on Kalnik-Igrišče site (as well as in Serbia and Italy) were represented with the mark "xxx" ("very much"). In Hungary spelt (T. aestivum ssp. spelta) was recorded as "very much", representing 1000-10 000 findings, while T. aestivum ssp. aestivum has only between 10 and 100 findings.

As well as at Kalnik-Igrišče, Setaria italica, with 100-1000 findings, also occurs in Austria. In Serbia there is one site with 10-100 findings, while in other countries it is either missing or recorded with the mark " $r$ " (less than 10 findings).

Since it is not possible to distinguish the grains of the cultivated form of oat (Avena sativa) from the wild weed forms such as A. sterilis and A. fatua, oats from archaeological layers were usually determined as Avena sp. Only if good preserved parts of florets (esp. lemma and parts of rachilla) are present, it may be possible to distinguish Avena species. It is therefore difficult to determine when its cultivation really begun. The oat (at Kalnik-Igrišče 68 remains were recorded) is also found in several sites in Austria and Italy, but in Hungary there are no confirmed findings for the Bronze Age. Very probably, the oat started its evolution under domestication not as a crop but by the evolution of the weedy types that infested cultivated wheat and barley. Definite indications of domestication appear first in Europe (the Czech Republic and Slovakia) in the 2nd and 1st millennia BC [23].

Secale cereale (rye) at the Kalnik-Igrišče site was rare. In the whole territory of Hungary, between 10 and 100 findings were reportedly found. The records of rye from the late Neolithic and the Bronze Age are, compared to barley and wheat, very occasional and the assumption is that at first rye was just tolerated as a weed in crops and its separate cultivation did not begin before the Iron Age [23].

The faba bean (Vicia faba) is the legume that was found in all the surrounding countries and it was labeled with the mark xxx (1000-10 000) at Kalnik-Igrišče, as it is in a similar Italian site; Ganglegg/Schluderns [24]. It is interesting to note that in Hungary Vicia faba was recorded only rarely (less than 10 findings). Lentils (Lens culinaris) were also recorded in all the researched countries; Serbia has the site (Feudvar) with the most listed lentil macrofossils. Peas (Pisum sativum) is a typical cultivated plant of the Bronze Age in our region, but at the Kalnik-Igrišče site we recorded only 11 questionable findings, so we cannot claim with certainty that it was bred (or consumed).

The remains of the apple fruit (Malus sylvestris), cornelian cherry (Cornus mas) and acorns of oak (Quercus sp.) at Kalnik-Igrišče suggest the collecting activity of the population. These three species have been a part of traditional nutrition in rural Croatia $[25,26]$.

It is assumed that these remains originate from the vicinity of the site, where they grew as native species. The species listed were used not only in human nutrition but also as a supplement food for animals. These species have been reported in Italy, Hungary and Serbia (Appendix S1). It is interesting to note that, although many localities from Austria were taken for comparison, there were no findings of remains of these useful trees. On the other hand, in Italy the frequency of the cornelian cherry is very high (12 sites).

Weeds at Kalnik-Igrišče site were rare due to the fact that they were found in the house, where the food was obviously already prepared for consumption. Regardless of that, it may be noted that the weed species found at KalnikIgrišče were frequently mentioned also in research from Serbia, Italy, Hungary and Austria. In particular there are numerous records of Bromus arvensis and Galium spurium in Feudvar (Serbia), and findings of Bromus secalinus in Kulm (Austria). Some weed species, like Bromus secalinus, were found at some sites in carbonized stew form, which leads us to conclusion that it was tolerated in crops and consumed by the human population of that time [27]. In some countries, like for example Poland, B. secalinus was consumed as an admixture with cultivated cereal until the early 20th century [28].

Appendix S1 lists all Bronze Age sites with literature available to us. However only a few sites entirely, or in a large part, fit the context from which the samples were taken at the Kalnik-Igrišče site (some samples were collected from the cremation altar, out of the pit, mine etc.). Therefore we would like to single out the Austrian site Kulm bei der Trofaiach [27], which according to its position (hill settlement at an altitude of $886 \mathrm{~m}$ a.s.l.) and the location from where the samples were taken (a wooden house destroyed by fire), is the site most similar to Kalnik-Igrišče. A detailed comparison between those two sites was made.

At both sites four subspecies of wheat were recorded; however, the ratio of individual species was significantly different (Fig. 6). A comparison with other Austrian sites gives us grounds to conclude that einkorn wheat in the Bronze Age was not very widespread in these areas and that it was only a small part of the cereal diet of the local population.

For both sites, Panicum miliaceum and Hordeum vulgare are one of the four most numerous species. At the KalnikIgrišče site they are the most numerous macrofossils, while at the Kulm site, T. turgidum ssp. dicoccon and Bromus secalinus are more frequent. Due to the very large number of weed species Bromus secalinus, Stika [27] suggests that this species in those days was tolerated in crops and even deliberately sown together with wheat for later consumption.

At both sites three species of edible legumes were recorded: Vicia faba, Lens culinaris and Pisum sativum. Vicia faba was in both cases the most numerous and confirmed its status as the main legume of that period in these areas. The percentage of lentil was higher in Kalnik-Igrišče (7.1\%) than in Kulm (0.09\%), while the number of pea findings was in both cases almost negligible (11 cf. / 1 finding).

As far as weed species are concerned, Galium aparine and Echinochloa crus-galli have been recorded at both sites. Other weed species do not match, but they are not numerous and do not affect much the global composition of species found at the sites.

Remains of useful tree species were not found at Kulm, while at Kalnik-Igrišče the number of apple findings (Malus sylvestris) was significant (242 residues). 


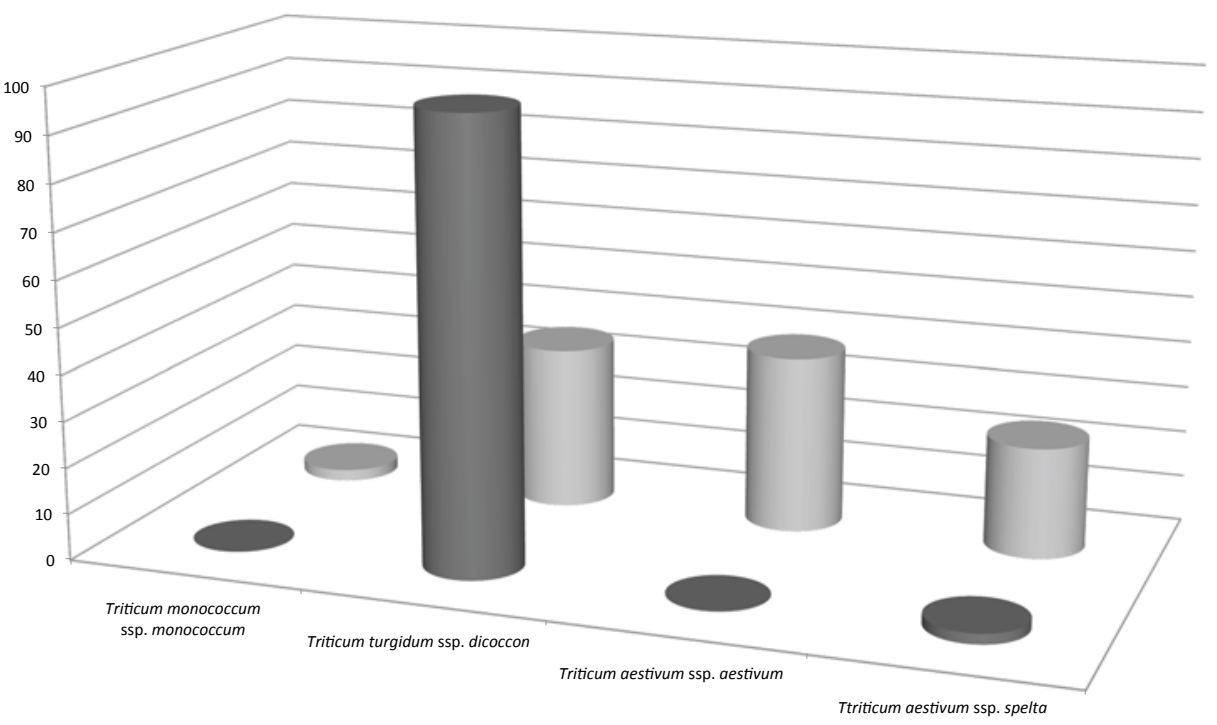

Fig. 6 Percentage of each wheat subspecies on the site Kalnik-Igrišče (light bars) and Kulm bei der Trofaiach (dark bars).

Spruce (Picea abies) occurred relatively frequently (71 leaf fragment remains) at the Kulm site. This woody species is likely to be present near Kulm, while on Mount Kalnik it did not appear (in large numbers).

Other plant taxa found at both sites are rare and just some of them (like Cornus mas, Avena sp. and Secale cereale) can have indicator values for the eating habits of the local population. A comparison of the measured dimensions of carbonized seeds/fruits for the species Triticum aestivum ssp. aestivum, T. turgidum ssp. dicoccon, T. monococcum ssp. monococcum (syn. Triticum monococcum, einkorn wheat), T. aestivum ssp. spelta, Panicum miliaceum, Setaria italica, Vicia faba and Lens culinaris from the Kalnik-Igrišče site with the dimensions of carbonized seeds/fruits of the same species from the Late Bronze Age site Stillfried an der March [20] is shown in Tab. 2. From this table it is evident that the average sizes of all seeds/fruits of all species from Kalnik-Igrišče are slightly higher than the average sizes of the same species from the site Stillfried an der March. The only exception is the $V$. faba seed, in which the difference in size is greater than $2 \mathrm{~mm}$. This small difference in dimensions may indicate long or short-term favorable conditions on the Kalnik-Igrišče site for cultivating the listed cereals and pulses, or perhaps that the inhabitants of Kalnik-Igrišče were successful farmers. But it is also possible that some size differences appeared due to different methods of measurement.

\section{Conclusion}

An analysis of 69116 plant macrofossils from the Late Bronze Age site Kalnik-Igrišče showed that $98 \%$ of the findings belong to cultivated species (cereals and legumes), and the remaining $2 \%$ of the remains are useful tree species, the fruits of which were gathered for food by residents, and weeds, which were accidentally brought to the investigated house.
The average dimensions of plant remains from KalnikIgrišče, compared with the dimensions of macrofossils from a similar Bronze Age site Stillfried an der March [20], are all slightly larger (up to max. $2 \mathrm{~mm}$ in length - Vicia faba seed).

The most important plant food at Kalnik-Igrišče were cereals, with Panicum miliaceum and Hordeum vulgare appearing in the largest numbers. Four subspecies of wheat were found (Triticum turgidum ssp. dicoccum, T. monococcum ssp. monococcum, T. aestivum ssp. spelta and T. aestivum ssp. aestivum), while the species T. monococcum ssp. monococcum had the lowest and T. aestivum ssp. aestivum the highest importance. Among the legumes, the species Vicia faba and Lens culinaris were certainly consumed (cultivated) and possibly Pisum sativum as well. The fruits of useful trees found, Malus sylvestris, Cornus mas and Quercus sp. suggest that the local population was engaged in the collecting activity, which helped them supplement their diet and possibly that of their livestock.

In the studied area (Croatia, Bosnia and Herzegovina, Slovenia, Austria, Hungary, Italy and Serbia) in the Bronze Age, the most commonly used cereals were Hordeum vulgare, Triticum turgidum ssp. dicoccum, T. aestivum ssp. aestivum, Panicum miliaceum and to a lesser extent Triticum monococcum ssp. monococcum. The legumes (Vicia faba, Lens culinaris and Pisum sativum) appear at the sites in smaller numbers than cereals, but they always accompany them and have a significant impact on the population's diet. For species Secale cereale and Avena sp. there is no reliable proof that they were deliberately bred at that time and it is assumed that they grew as weeds among the cultivated cereals. There is no reliable evidence of the cultivation of the species Setaria italica, either. Similar weed species appear throughout the area, while it is assumed that the species Bromus secalinus was tolerated in crops and also consumed, due to the large number of findings at the Austrian site of Kulm. 
Tab. 2 Comparison of the dimensions of carbonized seeds/fruits found on the Kalnik-Igrišče site, with carbonized seeds/fruits of the same species from the site Stillfried an der March.

\begin{tabular}{|c|c|c|c|c|c|c|}
\hline & \multicolumn{3}{|c|}{ Kalnik-Igrišče } & \multicolumn{3}{|c|}{ Stillfried an der March } \\
\hline & $\mathbf{L}(\mathbf{m m})$ & $\mathrm{W}(\mathbf{m m})$ & $\mathbf{H}(\mathbf{m m})$ & $\mathbf{L}(\mathbf{m m})$ & $\mathrm{W}(\mathbf{m m})$ & $\mathbf{H}(\mathbf{m m})$ \\
\hline Triticum aestivum ssp. aestivum & $4.68(3.93-5.43)$ & $3.72(3.01-4.46)$ & $3.13(2.52-3.98)$ & $4.46(4.1-5.0)$ & $3.36(3.0-3.8)$ & $2.69(2.4-3.0)$ \\
\hline T. turgidum ssp. dicoccon & $6.18(5.15-7.41)$ & $3.30(2.74-4.23)$ & $3.07(2.42-3.73)$ & $5.2(4.5-6.0)$ & $2.5(2.0-2.8)$ & $2.3(2.1-2.6)$ \\
\hline T. monococcum ssp. monococcum & $5.99(5.25-7.36)$ & $2.84(2.27-3.75)$ & $3.06(2.61-3.76)$ & $5.2(4.6-5.7)$ & $2.1(1.7-2.7)$ & $2.5(2.3-2.8)$ \\
\hline T. aestivum ssp. spelta & $6.10(4.32-8.77)$ & $3.34(2.70-4.07)$ & $2.60(2.07-3.29)$ & $5.24(3.9-6.0)$ & - & $2.23(1.8-2.6)$ \\
\hline Panicum miliaceum & $2.19(1.76-2.64)$ & $2.12(1.69-2.57)$ & $1.82(1.28-2.32)$ & $1.86(1.7-2.0)$ & $1.53(1.4-1.7)$ & - \\
\hline Setaria italica & $1.57(1.36-1.80)$ & $1.44(1.21-1.69)$ & $1.08(0.84-1.35)$ & $1.41(1.21-1.6)$ & $1.20(1.1-1.3)$ & - \\
\hline \multirow[t]{2}{*}{ Pisum sativum } & $5.31(4.94-5.97)$ & $5.15(4.81-5.50)$ & $4.98(4.58-5.21)$ & & $2 \mathrm{r}(\mathrm{mm})$ & \\
\hline & & & & & $3.44(3.2-3.6)$ & \\
\hline \multirow[t]{2}{*}{ Vicia faba } & $7.47(5.79-9.66)$ & \multirow[t]{2}{*}{$5.89(4.38-7.36)$} & $5.96(4.85-7.61)$ & \multirow[t]{2}{*}{5.5} & \multirow[t]{2}{*}{4.7} & \\
\hline & $2 \mathrm{r}(\mathrm{mm})$ & & $2 \mathrm{r}(\mathrm{mm})$ & & & \\
\hline Lens culinaris & & $3.36(2.39-4.13)$ & & & $2.91(2.6-4.0)$ & \\
\hline
\end{tabular}

$2 \mathrm{r}$ - diameter.

\section{Acknowledgments}

We would like to thank student Ivana Ribić for helping us with analysis of few samples. Many thanks to reviewers of this article on many useful tips and comments, which helped us improve our paper and make it more understandable. Thanks to Mr. McMaster for helping us with language corrections. The study was financed from the research project of the Ministry of Science, Technology and Sports of the Republic of Croatia "The genesis and development of Bronze Age communities in northern Croatia" (197-1970685-0689).

\section{Authors' contributions}

The following declarations about authors' contributions to the research have been made: writing the manuscript, conducting the archaeobotanical research: SM; giving the scientific view into the archaeobotanical context of the samples: SM, RŠ; chief of the archaeological excavations at Kalnik: SK; organizing the collecting and analysing of the archaeological data, giving the scientific view into the archaeological context of the samples: SK, AK; research designing, mentorship of archaeobotanical research: RŠ.

\section{Competing interests}

No competing interests have been declared.

\section{Supplementary material}

The following supplementary material for this article is available online at http://pbsociety.org.pl/journals/index.php/asbp/rt/suppFiles/ asbp.2015.015/0:

1. Appendix S1: the list and relative abundance of plant species found on the site Kalnik-Igrišče and comparison with findings from the surrounding bronze age sites from Croatia, Slovenia, Bosnia and Herzegovina, Serbia, Italy, Austria and Hungary.

\section{References}

1. Šoštarić R. Karbonizirani biljni ostaci iz prapovijesnog lokaliteta u Novoj Bukovici na položaju Sjenjak. Pril Inst Aarheol Zagrebu. 2001;18:79-82.

2. Hänsel B, Mihovilić K, Teržan B. Monkodonja, utvrđeno protourbano naselje starijeg i srednjeg brončanog doba kod Rovinja u Istri. Histria Arch. 1997;28:37-107.
3. Burušić-Matijašić K. Monografije i katalozi 9. Pula: Arheološki muzej Istre; 1998.

4. Gyulai F. Archaeobotany in Hungary - seed, fruit and beverage remains in the Carpathian Basin from Neolithic to the Late Middle ages. Budapest: Archaeolingua Alapitvany; 2010.

5. Karavanić S, Okroša Rožić L, Kudelić A, Karavanić I, Mareković S. Rezultati dosadašnjih istraživanja. Križevci: Likovna galerija Gradskog muzeja; 2011.

6. Karavanić S. The urnfield culture in continental Croatia. Oxford: British Archaeological Reports; 2009. (BAR International Series).

7. Veel M, Fieller N. Sampling seeds. J Archaeol Sci. 1982;9:287-298. http://dx.doi.org/10.1016/0305-4403(82)90024-3

8. Ribić I. Biljne namirnice u prehrani stanovništva naselja Kalnik-Igrišče u kasnom brončanom dobu [Master thesis]. Zagreb: University of Zagreb; 2012.

9. Neef R, Cappers RTJ, Bekker RM. Digital atlas of economic plants in archaeology. Groningen: Barkhuis \& Groningen, University library Groningen; 2012.

10. Cappers RTJ, Bekker RM, Jans JEA. Digitale Zadenatlas van Nederland. Groningen: Barkhuis \& Groningen, University library Groningen; 2006.

11. Heinisch O. Samenatlas der wichtigsten Futterpflanzen und ihrer Unkräuter. Berlin: Deutsche Akademie der Landwirtschaftswissenschaften zu Berlin; 1955.

12. Kohler-Schneider M. Prähistorische Getreidefunde, eine Bestimmungshilfe für verkohlte Korn- und Druschreste. Wien: Institut für Botanik; 2001.

13. Jacomet S. Practical course: identification of archaeological plant macrofossils (seeds and fruits). Basel: IPNA, Universität Basel; 2010.

14. Hršak J. Karbonizirani makrofosili s prapovijesnog lokaliteta KaptolGradci kraj Požege [Master thesis]. Zagreb: University of Zagreb; 2009.

15. Kohler-Schneider M. Contents of a storage pit from late Bronze Age Stillfried, Austria: another record of the "new" glume wheat. Veg Hist Archaeobot. 2003;12:105-111. http://dx.doi.org/10.1007/ s00334-003-0010-y

16. Palmer C. Paleoeconomic and paleoenviromental studies: 1 . The 
carbonized macroscopic plant remains. In: Harding A, Ostoja-Zagorski J, Palmer C, Rackham J, editors. Sobiejuchy: a fortified site of the Early Iron Age in Poland. Warsaw: Institute of Archaeology and Ethnology, Polish Academy of Science; 2004. p. 66-120.

17. Wiethold J. Archäologische Untersuchungen im Trassenverlauf der Bundesautobahn A8 im Landkreis Merzig-Wadern. Saarbrücken: Beiheft $4 ; 2000$. p. 80-83

18. Rothmaler W, Padberg W. Beiträge zur Frühgeschichte der Landwirtschaft III. Berlin: Deutsche Akademie der Landwirtschaften zu Berlin; 1957

19. Cappers RTJ, Neef R. Handbook of plant palaeoecology. Groningen: Barkhuis; 2012.

20. Kohler-Schneider M. Verkohlte Kultur- und Wildpflanzenreste aus Stillfried an der March als Spiegel spätbronzezeitlicher Landwirtschaft im Weinviertel, Niederösterreich. Mitteilungen der Prähistorischen Kommission 37. Wien: Verlag der Österreichischen Akademie der Wissenschaften; 2001.

21. Mareković S, Šoštarić R. The comparison between the influence of flotation and wet sieving on certain carbonized legumes and cereals remains. In: Miloglav I, editor. Znanstveni skup "Metodologija i arheometrija - stanje i smjernice. Zagreb: Odsjek za arheologiju, Filozofski fakultet Sveučilišta u Zagrebu; 2013. p. 20-21.

22. Stika HP, Heiss A. Plant cultivation in the Bronze age. In: Fokkens
$\mathrm{H}$, Harding A, editors. The European Bronze Age. Oxford: Oxford University Press; 2013. p. 348-369. http://dx.doi.org/10.1093/ oxfordhb/9780199572861.013.0019

23. Zohary D, Hopf M. Domestication of plants in the Old World, the origin and spread of cultivated plants in West Asia, Europe and Nile Valley. New York, NY: Oxford University Press; 2000.

24. Schmidl A, Oeggl K. Subsistence strategies of two Bronze Age hill-top settlements in eastern Alps-Friaga/Bartholomäberg (Voralberg, Austria) and Ganglegg/Schluderns (South Tyrol, Italy). Veg Hist Archaeobot. 2005;14:303-312. http://dx.doi.org/10.1007/s00334-005-0088-5

25. Dolina K, Łuczaj Ł. Wild food plants used on the Dubrovnik coast (south-eastern Croatia). Acta Soc Bot Pol. 2014;83(3):175-181. http:// dx.doi.org/10.5586/asbp.2014.029

26. Łuczaj Ł, Fressel N, Perković S. Wild food plants used in the villages of the Lake Vrana Nature Park (northern Dalmatia, Croatia). Acta Soc Bot Pol. 2013;82(4):275-281. http://dx.doi.org/10.5586/asbp.2013.036

27. Stika HP. Pflanzenreste aus der Höhensiedlung der späten Urnenfelderzeit am Kulm bei Trofaiach. Wien: BDA; 2000. p. 163-168. (Fundberichte Österreich; vol 38).

28. Łuczaj Ł, Szymański WM. Wild vascular plants gathered for consumption in the Polish countryside: a review. J Ethnobiol Ethnomed. 2007;3:17. http://dx.doi.org/10.1186/1746-4269-3-17 